\title{
A Igreja Evangélica Assembleia de Deus e as tensões doutrinárias para o diálogo inter-religioso
}

\author{
Gunnar Nascimento Chaves ${ }^{1}$ \\ Roberto Hofmeister Pich ${ }^{2}$
}

\section{Resumo}

Neste artigo, busca-se refletir sobre as perspectivas de diálogo inter-religioso pela Igreja Evangélica Assembleia de Deus (Brasil), a partir de suas posições doutrinárias. Inicia-se com a caracterização de aspectos históricos e das produções literárias da Assembleia de Deus, enfatizando em seguida a sua tendência apologética. São apresentados elementos necessários para o diálogo inter-religioso, segundo a pesquisa atual em teologia, os quais são, então, contrapostos com as doutrinas assembleianas. Mostra-se que, sobretudo a partir da sua Declaração de Fé, a relação da Assembleia de Deus com outras tradições religiosas assume traços fundamentalistas e exclusivistas. Questionase, ao final, sobre possibilidades de mudanças de posição nesse tocante.

Palavras-chave: Diálogo inter-religioso. Assembleia de Deus. Fundamentalismo. Exclusivismo.

\begin{abstract}
In this article, we make the attempt of reflecting on perspectives of interreligious dialogue by the Evangelical Church Assembly of God (Brazil), based on its doctrinal teachings. We begin by characterizing historical aspects and the literary materials produced by the Assembly of God, emphasizing its apologetic tendency. Necessary elements for interreligious dialogue, according to current research in theology, are presented. These elements are then contrasted with doctrines of the Assembly of God. Based above all on the Declaration of Faith, we show that the relationship of the Assembly of God with other religious traditions assumes fundamentalist and exclusivist traces. At the end, we question about possibilities of change regarding those attitudes.
\end{abstract}

Keywords: Interreligious Dialogue. Assembly of God. Fundamentalism. Exclusivism.

\section{Introdução}

Em um mundo permeado por conflitos étnicos, territoriais, políticos, econômicos e religiosos, o diálogo inter-religioso se apresenta como uma bandeira

\footnotetext{
${ }^{1}$ Mestrando do Programa de Pós-Graduação em Teologia da PUCRS, graduado em Psicologia pela UNISUL e em Teologia pela Faculdade Refidim; e-mail: gunnarchaves@hotmail.com

2 Professor do Programa de Pós-Graduação em Teologia e do Programa de Pós-Graduação em Filosofia da PUCRS; e-mail: roberto.pich@pucrs.br
} 
branca. Embora haja quem pense que o diálogo inter-religioso seja essencialmente uma tentativa de relativização das religiões, o seu intuito é, antes, mesmo reconhecendo e compreendendo diferenças, buscar aproximações teóricas e práticas, estabelecer acordos e harmonia entre as diversas posições religiosas e promover a paz. No entanto, existem religiões e confissões ou denominações intrareligiosas que ainda apresentam resistência diante de tal possibilidade de diálogo.

Neste trabalho, apresenta-se como exemplo a Igreja Evangélica Assembleia de Deus - abreviada, doravante, como AD -, cuja historicidade forjou a sua identidade, fazendo dessa instituição uma muralha aparentemente intransponível ao diálogo inter-religioso. O fundamentalismo e o exclusivismo estrutural, desenvolvidos historicamente a partir das posições soteriológicas, cristológicas e apologéticas dos líderes e fieis da $\mathrm{AD}$, colocam-se contrários à possibilidade de diálogo inter-religioso. Com base em sua Declaração de Fé e de outras literaturas publicadas pela editora Casa Publicadora das Assembleias de Deus (CPAD), buscar-se-á apresentar, de modo sucinto, algumas das posições dessa instituição evangélica.

\section{Aspectos históricos da Assembleia de Deus}

A Igreja Evangélica Assembleia de Deus é uma instituição centenária, fundada em 18 de junho de 1911, pelos missionários suecos Gunnar Vingren e Daniel Berg. Os jovens missionários vieram dos Estados Unidos da América. Lá, haviam sido influenciados pelo Movimento Pentecostal. Depois de receberem o batismo com o Espírito Santo, perceberam-se “direcionados" por Deus para viajar ao Brasil, em missão evangelizadora. Chegaram em terras brasileiras em 19 de novembro de 1910, instalando-se na cidade de Belém do Pará3.

Foram tempos difíceis para os dois missionários. O seu trabalho era grandemente limitado pelas dificuldades com o uso da língua portuguesa, pelos contrastes culturais e pela escassez de recursos financeiros. Nessa época, já havia, no Brasil, diversas igrejas evangélicas, entre elas, por exemplo, a Igreja Presbiteriana, a Igreja Batista e a Congregação Cristã - sendo essa última, fundada

3 MORAES, Isael de Araújo de. História do Movimento pentecostal no Brasil. Rio de Janeiro: CPAD, 2016, p. 34. 
em 1910, a primeira igreja pentecostal a se estabelecer no Brasil4. No começo, os trabalhos de Gunnar Vingren e Daniel Berg ocorreram em conjunto com irmãos da Igreja Batista. Contudo, as diferenças doutrinárias concernentes ao batismo no Espírito Santo, com a evidência do "falar em línguas estranhas" (glossolalia) e as demais manifestações dos dons do Espírito Santo5, forçaram os missionários a romper com aquela instituição e fundar uma nova igreja, que, de início, tinha o nome de Missão da Fé Apostólica6 ${ }^{6}$

Desde 18 de junho de 1911, a instituição Assembleia de Deus vem crescendo exponencialmente, destacando-se, há algumas décadas, como a maior denominação evangélica no Brasil7. De acordo com o Censo de 2010, o número de fiéis ultrapassava a casa dos 12 milhões de membros, número esse que representava, então, $6 \%$ da população nacional ${ }^{8}$. Hoje, estima-se que a Assembleia de Deus no Brasil possua 22,5 milhões de membros, mais de 35 mil ministros e cerca de 100 mil templos espalhados por todo o Brasil 9.

4 A partir da atuação do missionário Louis Francescon. Cf. MENESES, Jonatas Silva. Igreja Evangélica Assembleia de Deus: movimento, continuidade e mudanças. In: Revista Lusófona de Ciência das Religiões. Ano X, nn. 18-19, 2013, p. 155.

5 Há consenso entre pesquisadores em que a marca distintiva da vida espiritual, na perspectiva assembleiana, esteve historicamente centrada no batismo com o Espírito Santo acompanhado do dom espiritual de falar em línguas estranhas, caráter distintivo esse que se busca preservar, não sem tensões e margens de assimilação, face às ênfases na cura divina e na prosperidade. Esses últimos "dons" são caracteristicamente associados à vida no Espírito segundo a interpretação dos movimentos (deuteropentecostais e) neopentecostais. Cf. MENESES, Jonatas Silva. Igreja Evangélica Assembleia de Deus: movimento, continuidade e mudanças, p. 157-159. Cf. também FERREIRA, Ismael de Vasconcelos. Pentecostalismo e secularização: da rigidez doutrinária ao pluralismo religioso. In: Horizonte. Ano 10, n. 28, 2012, p. 1463-1464. De todo modo, é justo afirmar que o perfil teológico da $\mathrm{AD}$ contém também, marcantemente e desde os seus primórdios, uma moral conservadora focada nas parêneses do Novo Testamento e uma visão milenarista, prétribulacionista, do tempo histórico vivido, de evangelização combativa, de incessante chamado à conversão e na espera da vinda de Cristo (parusia), quando os verdadeiros crentes serão repentinamente arrebatados.

${ }^{6}$ CADB (Convenção da Assembleia de Deus no Brasil). História Centenária da Assembleia de Deus no Brasil [E-book], p. 25-28. Disponível in: < http://portalcadb.com/wpcontent/uploads/2017/12/ebook-historia-da-assembleia-de-deus-cadb.pdf $>$. Acesso em: 18 de maio de 2019.

7 Segundo FRESTON, Paul. Breve história do pentecostalismo: 1. A Assembléia de Deus. In: ANTONIAZZI. Alberto et alii (orgs.). Nem anjos nem demônios: interpretações sociológicas do pentecostalismo. Petrópolis: Vozes, 1994, p. 71, já no começo dos anos 1960 a AD era tida como a maior igreja protestante não só do Brasil, mas da América Latina.

8 BRASIL, IBGE. Censo Demográfico 2010: características gerais da população, religião e pessoas com deficiência. Rio de Janeiro: IBGE, 2010. Disponível in: https://biblioteca.ibge.gov.br/visualizacao/periodicos/94/cd_2010_religiao_deficiencia.pdf.

Acesso em 12 de junho de 2019.

9 MESQUITA, Antônio. Assembleia de Deus no Brasil é a maior do mundo. Disponível in: https://fronteirafinal.wordpress.com/2011/07/02/assembleia-de-deusbrasil-maior-do-mundo.

Acesso em 20 de junho de 2019. Sobre a estratégia de expansão e crescimento no número de fiéis, 


\section{Uma instituição "ainda" hermética}

A Igreja Evangélica Assembleia de Deus vem promovendo ao longo de sua história algumas mudanças e alterações positivas em seus "usos e costumes", modificando e adaptando discursos e práticas. No entanto, o seu referencial teológico continua sendo exclusivista e fundamentalista, buscando salvaguardar alguns dos pilares de seu tradicionalismo historicamente construído. Dentre esses pilares estão a doutrina soteriológica e o forte movimento apologético da $\mathrm{AD}$ frente ao mundo secularizado e a outras tradições religiosas, podendo isso ser observado em suas pregações inflamadas, não raro carregadas de proselitismo.

De acordo com A. S. Lima, a forte tendência apologética da Igreja Evangélica Assembleia de Deus é um reflexo do período em que a instituição ainda "germinava” no Brasil. Segundo o pesquisador, o crescimento da AD ocorreu em um período em que a religiosidade popular era majoritariamente católica, com um restrito campo de influência do protestantismo. À época, na Igreja Católica as missas eram celebradas em latim, na Igreja Luterana os cultos eram ministrados em alemão e na Igreja Anglicana a língua de culto era o inglês. A única igreja pentecostal de então, ou seja, a Congregação Cristã no Brasil, ordenava os cultos no idioma italiano. Ademais, as religiões indígenas e os cultos afro-brasileiros eram bastante fortes. Nesse contexto, os missionários suecos Gunnar Vingren e Daniel Berg foram inicialmente rechaçados ${ }^{10}$.

Com base nesse contexto e nessa experiência histórica de rejeição e separação, a Igreja Evangélica Assembleia de Deus ganhou a firme característica de posicionar-se contrariamente às tentativas de aproximação com outras

pela AD, nos anos 1990, na forma do projeto "Década da Colheita", que consolidou a AD como a maior igreja pentecostal brasileira, provocou certa revisão da ortodoxia dos "usos e costumes" e motivou, apesar da firme perspectiva apologética e de conquista religiosa, transformações em sua penetração na política, na sociedade e na mídia, cf. MARIN, Jérri Roberto. A Assembleia de Deus nos anos de 1990: a "Década da Colheita". In: Horizonte - Dossiê: Religião, Mercado e Mídia. Ano 12, n. 34, abr.-jun. 2014, p. 436-464. Cf. também MARIN, Jérri Roberto. A Assembleia de Deus e sua inserção no mercado religioso da década de 1990. In: Revista Brasileira de História das Religiões. ANPUH, n. 17, setembro de 2013 (publicada em 2014), p. 189-214.

${ }^{10}$ LIMA, Adriano Sousa. Assembleia de Deus no Brasil e o diálogo inter-religioso. In: Revista Caminhos de Diálogo - Pluralismo Religioso: Horizontes Abertos. Ano 2, n. 2, jan.-jul. de 2014, p. 44-45. Disponível in: <https://periodicos.pucpr.br/index.php/caminhosdedialogo/article/download/24579/23086>. Acesso em 18 de maio de 2019. 
denominações cristãs, desconsiderando o ecumenismo ${ }^{11}$. Isso se comprova com a recusa de grande parte das lideranças da $\mathrm{AD}$ em participar de qualquer evento que trate sobre o tema, posição que hoje está menos estimulada.

Com raras exceções, verifica-se por parte de representantes da instituição, tais como pastores e líderes, a construção de uma narrativa de “demonização" das demais religiões. De acordo com A. S. Lima, somente "um milagre" tornaria possível fazer da $\mathrm{AD}$ uma instituição que entrasse em diálogo pacífico - não confrontativo - com outras vertentes religiosas ${ }^{12}$. A instituição, portanto, "ainda" é bastante hermética, no sentido de ser fortemente fechada em si mesma, em sua compreensão da verdade bíblica. Percebem-se aspectos desse fechamento nos seus materiais literários, nas suas lições de Escola Bíblica Dominical e, oficialmente, na sua Declaração de Fé, como, por exemplo, na seguinte declaração: “A Bíblia é, portanto, a mensagem clara, objetiva, entendível, completa e amorosa de Deus, [...]. Nós a interpretamos sob a orientação do Espírito Santo, observando as regras gramaticais e o contexto histórico e literário"13.

\subsection{A soteriologia da Igreja Evangélica Assembleia de Deus}

Os fundadores da AD, Gunnar Vingren e Daniel Berg, chegaram ao Brasil pregando o batismo com o Espírito Santo e a salvação por meio da fé em Cristo. A doutrina da salvação, na compreensão assembleiana, tem como pilar a justificação do pecador pela fé, que significa, essencialmente, que o milagre da salvação ocorre por meio da fé em Jesus Cristo e que obras humanas não podem jamais salvar, mas, antes, denotam características de uma pessoa agraciada.

$\mathrm{O}$ método de interpretação bíblica adotado pela $\mathrm{AD}$ segue as posições advindas da Reforma Protestante, podendo ser chamado de "método históricogramatical”. Esse método é também chamado de "fundamentalista”, em razão de

\footnotetext{
${ }^{11}$ Sobre a rejeição formal do ecumenismo, pela $\mathrm{AD}$, desde o início dos anos 1960, cf. SOUSA, Bertone de Oliveira. Religião e negação da modernidade: a leitura fundamentalista da Bílbia nas revitas de Escola Bíblica Dominical da Assembléia de Deus. In: Revista Brasileira de História das Religiões. Ano 3, v. 7, maio de 2010, p. 226-227.

${ }^{12}$ LIMA, Adriano Sousa. LIMA, Adriano Sousa. Assembleia de Deus no Brasil e o diálogo interreligioso, 2014, p. 44.

${ }_{13}$ SILVA, Esequias Soares (org.). Declaração de Fé. Rio de Janeiro: CPAD, 2017, p. 16.
} 
6 | Opinião Filosófica, V. 10, n. 2, 2019 - Brasil Filosófico e seus pensadores

esforçar-se por encontrar o sentido simples e mais óbvio das palavras no texto bíblico, à luz do contexto histórico em que ele foi escrito ${ }^{14}$.

Embora seja tratado, de modo pejorativo, como fundamentalista e literalista, o método histórico-gramatical parte do pressuposto de que a Bíblia é divino-humana. Tal método foi amplamente usado pelos pais da(s) Reforma(s) Protestante(s), que entendiam a Bíblia, na medida em que o seu conteúdo é Cristo, como a sua própria e melhor intérprete. Isso é representado pela já antiga e bem conhecida máxima hermenêutica: "A Bíblia interpreta a si mesma"15.

Partindo desse método de interpretação consagrado pela tradição reformada, a Assembleia de Deus desenvolveu a sua soteriologia, entendendo, pois, a partir do sentido simples da Bíblia, a salvação como algo individual, e não coletivo. Ela ocorre por uma ação espiritual e miraculosa através da pessoa de Jesus Cristo, por quem Deus perdoa o ser humano e lhe chama à fé. A salvação concedida não é apenas um livramento da condenação eterna - do inferno -, mas é uma transformação integral do ser. Nesse sentido,

Há três passos necessários para um pecador receber a gloriosa salvação em Cristo. Primeiro, reconhecer mediante o evangelho que [é] pecador (Rm 3.23). Segundo, confiar em Jesus como o seu Salvador (At 16.31). Terceiro, confessar que o Senhor Jesus é o seu Salvador pessoal, "Visto que... com a boca se faz confissão para a salvação" (Rm 10.10). A obediência honesta do pecador movido por Deus a esses três passos resultará na sua salvação, operando o Espírito Santo e a Palavra. Isso não falha; não se trata de uma mera teoria; é a verdade de Deus sobre a salvação do pecador, revelada aos homens segundo a infalível Palavra de Deus e o testemunho da infinidade de salvos em Cristo por toda parte ${ }^{16}$.

A salvação, em resumo, é a redenção do ser humano do poder do pecado, a libertação do cativeiro espiritual, a retirada do pecador do poder das trevas do pecado e, finalmente, o retorno do exílio espiritual do pecador para Deus. A salvação inclui tudo o que Jesus Cristo realizou e ensinou para levar a humanidade pecadora à comunhão com um Deus santo ${ }^{17}$.

\footnotetext{
14 WEGNER, Uwe. Exegese do Novo Testamento: manual de metodologia. São Leopoldo; São Paulo: Sinodal; Paulus, 1998, p. 15.

${ }^{15}$ LOPES, A. N. A Bíblia e seus Intérpretes - uma breve história da interpretação. São Paulo: Cultura Cristã, 32014, p. 129.

${ }^{16}$ GILBERTO, Antônio et alii. Teologia sistemática pentecostal. Rio de Janeiro: CPAD, 2008, p. 335 .

${ }_{17}$ GILBERTO, Antônio et alii. Teologia sistemática pentecostal, p. 338.
} 
Todo o processo salvífico ocorre mediante a fé em Jesus Cristo. Nesse sentido, a justificação pela fé pode ser vista como uma ideia jurídica, relacionada à ideia de absolvição. A justificação se refere ao ato divino em que Deus, santo e justo, torna os pecadores aceitáveis diante d'Ele ${ }^{18}$. Na compreensão soteriológica assembleiana, as pessoas salvas são aquelas que, pela graça, reconhecem os seus pecados, confiam e creem em Jesus Cristo como o único capaz de perdoar os seus pecados e confessam Jesus Cristo como o seu Salvador pessoal. A partir dessa condição, as pessoas serão justificadas, regeneradas, santificadas e glorificadas.

\subsection{A apologética da Assembleia de Deus em seus materiais literários e lições de EBD}

Como já dito anteriormente, a Igreja Evangélica Assembleia de Deus está espalhada por todos os Estados do Brasil. Ela se destaca pela posição apologética, tendo como ferramenta de propagação dos ditames de sua fé a Casa Publicadora das Assembleias de Deus (CPAD), imprimindo Bíblias e produzindo livros, folhetos e revistas, com destaque para as lições de Escola Bíblica Dominical (EBD). Desde 1922 as Assembleias de Deus produzem o conteúdo das lições para a EBD. Publicados originalmente como suplemento do jornal Boa Semente, em Belém do Pará, os ensinos receberam, de início, o título de Ensinos Dominicais. Esse foi o embrião das atuais lições de EBD, que visam promover o discurso institucional ${ }^{19}$. Até hoje, as lições de EBD têm o propósito de uniformizar o ensino bíblicoteológico das Assembleias de Deus.

Com uma tradição de quase noventa anos, a revista Lições Bíblicas da CPAD é a principal responsável pela coesão doutrinária de nossa igreja no Brasil. De Norte a Sul e de Leste a Oeste, verificase que, salvo as questões de usos e costumes e pouquíssimas diferenças litúrgicas, as Assembleias de Deus são doutrinariamente coesas. [...] devemos nossa coesão doutrinária às revistas e ao trabalho voluntário de milhões de professores que, a

${ }^{18}$ GRENZ, Stanley J.; NORDLING, Cherith Fee. Dicionário de teologia. São Paulo: Vida, 200o, p. 78.

${ }^{19}$ A tese de que, pelas lições bíblicas nas revistas de $\mathrm{EBD}$ da $\mathrm{AD}$, promove-se um discurso fundamentalista e conservador em termos de doutrina teórica e moral é defendida por SOUSA, Bertone de Oliveira. Religião e negação da modernidade: a leitura fundamentalista da Bílbia nas revitas de Escola Bíblica Dominical da Assembléia de Deus, p. 223-250. 
cada domingo, ministram o mesmo conteúdo bíblico em nossas igrejas em todo o território nacional ${ }^{20}$.

De acordo com o site oficial da Editora, a CPAD foi introduzida no mercado editorial oficialmente em 13 de março de 1940, quando ela foi organizada juridicamente no Rio de Janeiro. Desde o seu surgimento até os dias atuais, a editora vem produzindo e fortalecendo as características ímpares e singulares da instituição eclesiástica que ela representa, a saber, através das Lições Bíblicas para a EBD, em todas as faixas etárias, revistas para jovens e obreiros ${ }^{21}$, livros devocionais, bíblicos e teológicos, bem como o jornal Mensageiro da Paz ${ }^{22}$.

São esses princípios que norteiam a prática pedagógica da CPAD: teologia sólida, ortodoxa, bíblica e apologética aliada a uma produção curricular baseada na psicologia do desenvolvimento do ser humano, ocorrido ao longo da vida e em suas distintas faixas etárias, não unicamente nas esferas cognitiva, física, social e moral, mas também e, principalmente, na espiritual. A Casa Publicadora das Assembleias de Deus entende que a saúde espiritual de uma igreja depende de um ensino correto das Escrituras Sagradas $[\ldots]^{23}$.

As lições para EBD têm o papel fundamental de massificar o conteúdo pentecostal, ou seja, ensinar as verdades cridas pela instituição, principalmente o continuísmo, a saber, uma corrente teológica adotada por pentecostais que entendem os dons espirituais (carismas) descritos pelo Apóstolo Paulo em 1 Coríntios 12-14 - especialmente em 1 Coríntios 12.4-11 - como dons espirituais correntes nos dias de hoje, para a edificação a Igreja. É preciso apontar que existe uma verdadeira "batalha teológica" contra os que são de fora. Em outras palavras, há uma luta apologética que busca incessantemente resistir às opiniões sobretudo de natureza moral - divulgadas em impressos oficiais (externos). Essa luta se dá, sobretudo, através das Lições Bíblicas para a EBD²4. Além disso, muitos

${ }^{20}$ CARVALHO, César Moisés. A importância das Lições Bíblicas na coesão doutrinária nas Assembleias de Deus no Brasil. CPADNEWS, 2010. Disponível in: http://cpadnews.com.br/ensinador-cristao/780/a-importancia-das-licoes-biblicas.html. Acesso em 18 de maio de 2019.

${ }^{21}$ Sejam mencionadas, aqui, a Revista da Escola Dominical e a Revista Obreiro.

${ }^{22}$ MORAES, Isael de Araújo. Dicionário do Movimento Pentecostal. Rio de Janeiro: CPAD, 2007, p. 165-167.

${ }^{23}$ CARVALHO, César Moisés A importância das Lições Bíblicas na coesão doutrinária nas Assembleias de Deus no Brasil, 2010.

${ }^{24}$ CADB (Convenção da Assembleia de Deus no Brasil). História Centenária da Assembleia de Deus no Brasil (E-book). Disponível in: < http://portalcadb.com/wp- 
livros produzidos pela editora CPAD, seja por autores nacionais ou internacionais, endossam essa perspectiva defensiva.

Assim, pois, entre os títulos característicos é possível encontrar os seguintes: Heresias e modismos: uma análise crítica das sutilezas de Satanás (2006), escrito por Esequias Soares; Seitas e heresias: um sinal do fim dos tempos (1987), escrito por Raimundo de Oliveira; Desmascarando as seitas (1996), escrito por Natanael Rinaldi e Paulo Romeiro; Resposta às seitas (2000), escrito por Norman Geisler e Ron Rhodes; Guia de seitas e religiões, escrito por Bruce Bickel e Stan Jantz; Apologia da fé cristã (1999), escrito por Abraão Pereira de Almeida; Manual de apologética cristã: defendendo os fundamentos da autêntica fé bíblica (2002), escrito por Esequias Soares; Cristo entre outros deuses: uma defesa da fé cristã numa era de tolerância (2000), escrito por Erwin W. Lutzer.

Esses e outros títulos apontam para o posicionamento teológico firme e a preocupação doutrinal da instituição, que reforçam o discurso apologético com uma finalidade proselitista.

\subsection{Posições da Assembleia de Deus em sua Declaração de Fé}

A Declaração de Fé das Assembleias de Deus foi promulgada em 22 de novembro de 2016, por uma Comissão Especial de pastores, sob a presidência da Convenção Geral das Assembleias de Deus no Brasil (CGADB), na pessoa de Pr. José Wellington Bezerra da Costa. O último nomeou tal Comissão Especial, no intuito de elaborar o credo ou a confissão de fé da $\mathrm{AD}$, denominado Declaração de $F e^{25}$.

Desde a fundação da Igreja Evangélica Assembleia de Deus, nunca houve, de fato, um documento oficial de confissão de fé. O que se tinha, desde 1969, era o conhecido "O que nós cremos", publicado inicialmente por Gunnar Vingren, em 16 de abril de 1919, no jornal Boa Semente, que, depois, tornou-se apenas o "Cremos". Esse documento não oficial de confissão consiste de 16 pontos específicos da fé pentecostal, na perspectiva assembleiana. Cremos:

content/uploads/2017/12/ebook-historia-da-assembleia-de-deus-cadb.pdf $>$. Acesso em 18 de maio de 2019, p. 56.

${ }^{25}$ SILVA, Esequias Soares (org.). Declaração de Fé, p. 11. 
1. Na inspiração divina verbal e plenária da Bíblia Sagrada, única regra infalível de fé e prática para a vida e o caráter cristão (2 Tm 3.14-17);

2. Em um só Deus, eternamente subsistente em três pessoas distintas que, embora distintas, são iguais em poder, glória e majestade: o Pai, o Filho e o Espírito Santo; Criador do Universo, de todas as coisas que há nos céus e na terra, visíveis e invisíveis, e, de maneira especial, os seres humanos, por um ato sobrenatural e imediato, e não por um processo evolutivo (Dt 6.4; Mt 28.19; Mc 12.29; Gn 1.1; 2.7; Hb 11.3 e Ap 4.11);

3. No Senhor Jesus Cristo, o Filho Unigênito de Deus, plenamente Deus, plenamente Homem, na concepção e no seu nascimento virginal, em sua morte vicária e expiatória, em sua ressurreição corporal dentre os mortos e em sua ascensão vitoriosa aos céus como Salvador do mundo (Jo 3.16-18; Rm 1.3,4; Is 7.14; Mt 1.23; $\mathrm{Hb}$ 10.12; Rm 8.34 e At 1.9);

4. No Espírito Santo, a terceira pessoa da Santíssima Trindade, consubstancial com o Pai e o Filho, Senhor e Vivificador; que convence o mundo do pecado, da justiça e do juízo; que regenera o pecador; que falou por meio dos profetas e continua guiando o seu povo (2 Co 13.13; 2 Co 3.6,17; Rm 8.2; Jo 16.11; Tt 3.5; 2 Pe 1.21 e Jo 16.13);

5. Na pecaminosidade do homem, que o destituiu da glória de Deus e que somente o arrependimento e a fé na obra expiatória e redentora de Jesus Cristo podem restaurá-lo a Deus (Rm 3.23; At 3.19 );

6. Na necessidade absoluta do novo nascimento pela graça de Deus mediante a fé em Jesus Cristo e pelo poder atuante do Espírito Santo e da Palavra de Deus para tornar o homem aceito no Reino dos Céus (Jo 3.3-8, Ef 2.8,9);

7. No perdão dos pecados, na salvação plena e na justificação pela fé no sacrifício efetuado por Jesus Cristo em nosso favor (At 10.43; Rm 10.13; 3.24-26; Hb 7.25; 5.9);

8. Na Igreja, que é o corpo de Cristo, coluna e firmeza da verdade, una, santa e universal assembleia dos fiéis remidos de todas as eras e todos os lugares, chamados do mundo pelo Espírito Santo para seguir a Cristo e adorar a Deus (1 Co 12.27; Jo 4.23; $1 \mathrm{Tm}$ 3.15; Hb 12.23; Ap 22.17);

9. No batismo bíblico efetuado por imersão em águas, uma só vez, em nome do Pai, e do Filho, e do Espírito Santo, conforme determinou o Senhor Jesus Cristo (Mt 28.19; Rm 6.1-6; Cl 2.12);

10. Na necessidade e na possibilidade de termos vida santa e irrepreensível por obra do Espírito Santo, que nos capacita a viver como fiéis testemunhas de Jesus Cristo (Hb 9.14; 1 Pe 1.15);

11. No batismo no Espírito Santo, conforme as Escrituras, que nos é dado por Jesus Cristo, demonstrado pela evidência física do falar em outras línguas, conforme a sua vontade (At 1.5; 2.4; 10.44-46; 19.1-7);

12. Na atualidade dos dons espirituais distribuídos pelo Espírito Santo à Igreja para sua edificação, conforme sua soberana vontade para o que for útil (1 Co 12.1-12);

13. Na segunda vinda de Cristo, em duas fases distintas: a primeira - invisível ao mundo, para arrebatar a sua Igreja antes 
da Grande Tribulação; a segunda - visível e corporal, com a sua Igreja glorificada, para reinar sobre o mundo durante mil anos (1 Ts 4.16, 17; 1 Co 15.51-54; Ap 20.4; Zc 14.5; Jd 1.14);

14. No comparecimento ante o Tribunal de Cristo de todos os cristãos arrebatados, para receberem a recompensa pelos seus feitos em favor da causa de Cristo na Terra (2 Co 5.10);

15. No Juízo Final, onde comparecerão todos os ímpios: desde a Criação até o fim do Milênio; os que morrerem durante o período milenial e os que, ao final desta época, estiverem vivos. E na eternidade de tristeza e tormento para os infiéis e vida eterna de gozo e felicidade para os fiéis de todos os tempos (Mt 25.46; Is 65.20; Ap 20.11-15; 21.1-4).

16. Cremos, também, que o casamento foi instituído por Deus e ratificado por nosso Senhor Jesus Cristo como união entre um homem e uma mulher, nascidos macho e fêmea, respectivamente, em conformidade com o definido pelo sexo de criação geneticamente determinado (Gn 2.18; Jo 2.1,2;Gn 2.24; 1.27).

Esses 16 pontos confessionais do "Cremos" foram publicados em todas as edições do jornal Mensageiro da Paz, sendo até o ano de 2016 o único documento que efetivamente expressava por escrito o pensamento doutrinário da Assembleia de Deus. Desde então, o referido texto passou a ser um extrato da Declaração de $F e ́$, que traz as verdades centrais da denominação ${ }^{26}$.

A obra Declaração de Fé é um documento eclesiástico que organiza, de forma escrita e sistemática, as crenças e práticas das Assembleias de Deus no Brasil que já são ensinadas nas igrejas desde a chegada ao país dos missionários fundadores, Daniel Berg (1884-1963) e Gunnar Vingren (1879-1933). O contexto social e político por si só exige uma definição daquilo em que a Igreja crê e daquilo que professa desde as suas origens. A Bíblia é a nossa única fonte de autoridade, a inerrante, infalível, completa e inspirada Palavra de Deus. As Escrituras Sagradas, no entanto, precisam ser interpretadas para que todos conheçam a sua mensagem ${ }^{27}$.

Nesse documento, os 16 pontos do "Cremos" foram trabalhados e desenvolvidos em 24 capítulos. O conteúdo apresentado são as “interpretações autorizadas das Escrituras e os ensinos oficiais das Assembleias de Deus no Brasil” 28. Dessa maneira, a Declaração de Fé tem o papel de salvaguardar a instituição contra falsas doutrinas, promovendo, assim, a coerência e a harmonia

\footnotetext{
${ }^{26}$ SILVA, Esequias Soares (org.). Declaração de Fé, p. 11. ${ }^{27}$ SILVA, Esequias Soares (org.). Declaração de Fé, p. 11.

${ }^{28}$ SILVA, Esequias Soares (org.). Declaração de Fé, p. 17.
} 
12 | Opinião Filosófica, V. 10, n. 2, 2019 - Brasil Filosófico e seus pensadores

do pensamento teológico, além de fortalecer a identidade da denominação e da sua marca pentecostal.

\section{O diálogo inter-religioso a partir do documento Diálogo e anúncio}

Antes de apontar para algumas concepções sobre o diálogo inter-religioso, cabe apresentar, de modo sucinto, para fins de comparação com a visão da $\mathrm{AD}$, quando e como iniciou o processo de abertura da Igreja Católica ao ecumenismo e a tal diálogo. Desde o Concílio Vaticano II, quando o axioma "não há salvação fora da Igreja” ganhou a sua devida ressignificação e novas propostas eclesiásticas foram estabelecidas, um novo olhar sobre as demais religiões foi instituído, na tentativa de estabelecer, de modo harmônico, um diálogo entre as religiões.

Dentre as ações conseguintes a essa nova tendência, encontra-se o documento Diálogo e anúncio, promulgado em 1991 pelo então Papa João Paulo II. O documento traz considerações sobre o "diálogo" com outras religiões, ou seja, um passo para além do próprio ecumenismo e em prol do anúncio de Cristo sem proselitismo, estabelecendo as bases teológicas para o diálogo inter-religioso em sentido estrito. Com efeito, essa perspectiva de minimizar conflitos e aumentar a abertura para o diálogo inter-religioso já havia surgido a partir do documento Diálogo e missão, de 1984, em que o termo "diálogo" era entendido como o conjunto das relações inter-religiosas, positivas e construtivas, com pessoas e comunidades de outros credos, para o conhecimento mútuo e o recíproco enriquecimento 29.

Acentuava-se, ali, a importância do diálogo para o desenvolvimento integral da pessoa humana, visando também extinguir as tensões e os conflitos entre as diversas culturas religiosas. Nesse sentido, Jacques Dupuis aponta para João Paulo II como um referencial positivo no processo de reflexão sobre a teologia das religiões. Foi João Paulo II quem estruturou teologicamente a hipótese de que o Espírito de Deus está presente e operante de forma universal na vida religiosa dos

\footnotetext{
${ }^{29}$ SILVA, José Barbosa da. Diálogo inter-religioso: tensões e perspectivas na interpretação da instrução diálogo e anúncio à luz da proposta teológica de Jacques Dupuis. Recife: Universidade Católica de Pernambuco (Dissertação - Mestrado em Ciências da Religião), 2013, p. 55.
} 
não cristãos e nas tradições religiosas a que eles pertencem ${ }^{30}$. Jacques Dupuis enfatiza que o documento declara que "aceitar e/ou afirmar" a presença e a ação universal do Espírito de Deus entre os não cristãos, bem como em suas tradições, representa a mais importante contribuição para a estruturação do diálogo interreligioso, indicando que o mistério da salvação é concebido como tendo lugar e vez também em povos e em culturas que não têm conhecimento ou consciência da pessoa de Cristo ${ }^{31}$.

Os cristãos são conscientes disto, graças à sua fé, enquanto os outros desconhecem que Jesus Cristo é a fonte de salvação. O mistério de salvação atinge-os, por caminhos conhecidos por Deus, graças à ação invisível do Espírito de Cristo. É através da prática daquilo que é bom nas suas próprias tradições religiosas, e seguindo os ditames da sua consciência, que os membros das outras religiões respondem afirmativamente ao convite de Deus e recebem a salvação em Jesus Cristo, mesmo se não o reconhecem como o seu Salvador ${ }^{32}$.

A proposta do diálogo inter-religioso apregoada por João Paulo II assumiu um lugar de enorme relevância, visando à superação de conflitos. Todavia, para que o diálogo aconteça de forma plena, um longo e complexo percurso precisa ser percorrido. Nesse sentido, Andrés Torres Queiruga esclarece os passos propostos por Jacques Dupuis para a meta de, ao final, implementar esse diálogo, isto é, segundo a adequada abordagem das assim chamadas três alternativas formais, que se interpõem: (i) abdicar o exclusivismo, (ii) compreender o inclusivismo e (iii) admitir o pluralismo, sem cair no relativismo absoluto33. Disso será tratado a seguir.

3o PONTIFÍCIO Conselho Para o Diálogo Inter-religioso. Diálogo e Anúncio. (1991) n. 40. Disponível in: http://www.vatican.va/roman_curia/pontifical_councils/interelg/documents/rc_pc_interelg_doc _19051991_dialogue-and-proclamatio_po.html. Acesso em 10 de maio de 2019.

${ }^{31}$ DUPUIS, Jacques. $O$ cristianismo e as religiões: do desencontro ao encontro. São Paulo: Loyola, 2004, p. 278-281.

${ }^{2}$ PONTIFÍCIO Conselho para o Diálogo Inter-religioso. Diálogo e anúncio. (1991) n. 29. Disponível in: http://www.vatican.va/roman_curia/pontifical_councils/interelg/documents/rc_pc_interelg_doc _19051991_dialogue-and-proclamatio_po.html. Acesso em 10 de maio de 2019.

33 QUEIRUGA, Andrés Torres. O diálogo das religiões. São Paulo: Paulus, 1997, p.17-18. 


\section{As alternativas formais para o diálogo inter-religioso}

Torres Queiruga afirma que as alternativas formais para o diálogo interreligioso, oferecidas por Dupuis, em que "abdicar”, “compreender” e "admitir” se tornam palavras-chave, partem da premissa de que se deve reconhecer, com respeito e tolerância, os elementos positivos existentes em todas as religiões. Justamente isso pode favorecer a aproximação entre as religiões 34 .

Segundo S. R. Paine, quando o praticante de uma tradição religiosa se depara com a necessidade de diálogo, três posições fundamentais podem ser adotadas por ele, a saber, o exclusivismo, o inclusivismo ou o pluralismo35. A posição do exclusivista é a de compreender a sua religião como a única real e verdadeira, destacando a sua própria confissão de fé ou a afirmação da posição religiosa pessoal, excluindo qualquer possibilidade de outra religião manifestar verdades absolutas ou dar acesso ao transcendente. As demais tradições religiosas não passam de meros erros ou falácias. O exclusivismo pode ser absoluto, quando as outras tradições são vistas como estando sob o poder do mal ou intimamente ligadas ao erro; ou pode ser menos categórico, quando há reconhecimento de elementos de verdade e valor fora da própria religião, mas mantém-se a afirmação de que só a sua posição traz a verdade absoluta36.

A posição inclusivista é a de compreender a sua religião como verdadeira, mas não em sentido absoluto, reconhecendo que nas demais tradições religiosas pode haver, implícita ou explicitamente, verdades essenciais e valores positivos. Ao reconhecer essa possibilidade, uma atitude positiva pode ser adotada para com as outras religiões. O inclusivismo geralmente não nega a possibilidade de salvação e de verdades nas demais religiões, afirmando que todas as principais religiões dizem essencialmente as mesmas coisas e possuem em si elementos centrais verdadeiros, de moralidade e de culto, alterando apenas o estilo, a linguagem e os elementos culturais. Em outra perspectiva, ainda, o inclusivismo pode também ser mais criterioso, a saber, admitindo alto grau de elementos

34 QUEIRUGA, Andrés Torres. O diálogo das religiões, p. 16-23.

35 PAINE, Scott Randall. Exclusivismo, inclusivismo e pluralismo religioso. In: Revista Brasileira de História das Religiões - Dossiê Identidades Religiosas e História, Ano 1, n. 1, 2008. Disponível in: http://www.dhi.uem.br/gtreligiao/pdf/11\%20Scott\%20Randall\%20Paine.pdf. Acesso em 18 de junho de 2019, p. 100.

36 PAINE, Scott Randall. Exclusivismo, inclusivismo e pluralismo religioso, p. 103. 
comuns incluídos em todas as religiões, mas insistindo em enormes e irredutíveis diferenças, mesmo sem fixar hierarquias entre as religiões37.

A posição pluralista é a de compreender a sua religião como uma religião verdadeira entre tantas. Adota-se por princípio a visão de que todas as religiões são basicamente iguais, entendendo-se a religião em uma perspectiva mais objetiva, secularizada ou não crente. Nesse sentido, segundo o pluralismo as demais tradições religiosas são equivalentes em valor salvífico e em verdade. Todavia, há um problema central no pluralismo, a saber, a sua tendência a vincular a religião a uma visão relativista, o que não parece ser algo positivo38.

De modo geral, pois, as três alternativas formais propostas por Jacques Dupuis para o diálogo inter-religioso têm em vista traçar um caminho harmonioso, na forma de ações que indicariam as etapas e mostrariam o rumo para que de fato o diálogo entre as religiões seja estabelecido, promovendo, dessa maneira, um ideal de paz mundial entre religiões ou na base das religiões.

\section{A Assembleia de Deus e as tensões doutrinárias para o diálogo inter- religioso}

Cabe lembrar, inicialmente, que a Igreja Evangélica Assembleia de Deus não expõe abertamente nenhuma posição sobre o diálogo inter-religioso. No entanto, o silêncio sobre o assunto, junto com a ênfase firme em suas próprias doutrinas de teor exclusivista, inferem, de certa forma, a impossibilidade de aceitação de um diálogo inter-religioso. A percepção vigente acerca da religião, na $\mathrm{AD}$, assimila a pretensão da fé cristã de ser o centro da expressão da vontade divina, única e absoluta. Como consequência, gera-se por parte da instituição, muitas vezes, a preferência por um isolamento, em prol da busca por pureza doutrinal, evitando possíveis influências externas e rejeitando mudanças paradigmáticas.

Diante do exposto sobre as Assembleias de Deus, as suas características históricas, os seus elementos doutrinários, a sua visão soteriológica, a sua forte posição apologética e a recente estruturação de sua Declaração de Fé, fica evidente

37 PAINE, Scott Randall. Exclusivismo, inclusivismo e pluralismo religioso, p. 100-101.
38 PAINE, Scott Randall. Exclusivismo, inclusivismo e pluralismo religioso, p. 101. 
16 | Opinião Filosófica, V. 10, n. 2, 2019 - Brasil Filosófico e seus pensadores

que essa denominação - como instituição religiosa cristã protestante, de matriz pentecostal - se encaixa no pensamento exclusivista39.

\subsection{O exclusivismo e a doutrina assembleiana}

$\mathrm{Na}$ ótica teológica da $\mathrm{AD}$, o cristianismo é por natureza exclusivista, afirmando de modo taxativo que a salvação só pode ser obtida mediante a fé em Cristo Jesus. Nas palavras de J. M. Vigil, exclusivistas entendem que tudo o que as demais religiões não cristãs podem oferecer constitui, na melhor das hipóteses, inúteis tentativas humanas de auto-justificação40.

Quando Dupuis afirma que, se o cristianismo procura sinceramente um diálogo com outras tradições, deveria antes de mais nada renunciar a toda pretensão de unicidade para a pessoa e a obra de Jesus Cristo como algo essencial e único da salvação, bem como reconhecer a presença oculta e operante de Cristo nas demais religiões não cristãs ${ }^{41}$, tais afirmações entram em confronto direto com a Declaração de Fé das Assembleias de Deus, que caminha em direção oposta:

Cremos, professamos e ensinamos que a salvação é o livramento do poder da maldição do pecado, e a restituição do homem à plena comunhão com Deus, a todos os que confessam a Jesus Cristo como seu único Salvador pessoal, precedidos do perdão divino: "A este dão testemunho todos os profetas, de que todos os que nele creem receberão o perdão dos pecados pelo seu nome" (At 10.43). Trata-se da restauração do relacionamento do ser humano com Deus por meio de Cristo: "Deus estava em Cristo reconciliando consigo o mundo, não lhes imputando os seus pecados" (2 Co 5.19). Somente a fé na morte expiatória de Jesus e o arrependimento podem remir o pecador e levá-lo ao Criador. Essa salvação é um ato da graça soberana de Deus pelo mérito de Jesus Cristo e não vem das obras: "Porque pela graça sois salvos, por meio da fé; e isso não vem de vós; é dom de Deus. Não vem das obras, para que ninguém se glorie" (Ef 2.8,9) ${ }^{42}$.

\footnotetext{
39 Sobre isso, cf. também MINA, Andréia Mendes de Souza. Pentecostalismo e alteridade: a demonização do outro no discurso da Assembléia de Deus. In: Revista Esboços. Ano 11, n. 11, 2004, p. 84-86.

40 VIGIL, José Maria. Teologia do pluralismo religioso: para uma leitura pluralista do cristianismo. São Paulo: Paulus, 2006, p. 244.

${ }^{41}$ DUPUIS, Jacques. $O$ cristianismo e as religiões: do desencontro ao encontro, p. 72-87.

${ }^{42}$ SILVA, Esequias Soares (org.). Declaração de Fé. p. 109. Ênfases em negrito dos autores.
} 
A adoção do exclusivismo salvífico em Cristo, aliado à adesão pessoal, consciente e explícita (professada) de Cristo como Salvador, não é convicção única da $\mathrm{AD}$; antes, outras igrejas evangélicas se posicionam da mesma forma, tais como diversas denominações de matriz reformada, por exemplo, a Igreja Presbiteriana, a Igreja Batista e a Igreja Congregacional, que também adotaram, no sentido explicitado, os cinco pilares ou as cinco cláusulas exclusivas doutrinais, formuladas com as expressões "sola" e "solus"43, dentre elas o "solus Christus". Nos espaços evangélicos protestantes, o discurso sobre a salvação "fora" de Cristo é inconcebível. Não há nenhuma justificativa para dizer que a salvação pode ser alcançada sem Cristo ou em se prescindindo de uma aceitação explícita da sua obra - a saber, mediante a fé. Pelo contrário, de acordo com o reconhecido Movimento Lausanne, os membros da Igreja de Jesus Cristo em todo o mundo afirmam com alegria o compromisso com o Deus vivo e com os seus propósitos de salvação através do Senhor Jesus Cristo 44. A perspectiva assembleiana compreende que Jesus Cristo é o elemento constitutivo - central, essencial e incontornável - para a salvação, dependendo a salvação plenamente da fé na sua pessoa e na sua obra única.

\subsection{O inclusivismo e a posição assembleiana}

Outro ponto decisivo para a $\mathrm{AD}$ é a questão da verdade. Não se trata de afirmar que a instituição é detentora da verdade, mas de insistir que ela defende como verdade absoluta os conteúdos do Livro no qual ela baseia a sua fé, a saber, a Bíblia ou Escritura Sagrada. Indo em outra direção, contudo, Jacques Dupuis afirma que existe mais verdade e graça em toda a extensa dinâmica da história das relações humanas do que no pequeno capital disponível da tradição cristã45. Por sua vez, Andrés Torres Queiruga afirma que Deus está se revelando e exercendo

\footnotetext{
43 Nas cláusulas exclusivas estão os pilares teológicos da Reforma Protestante, a saber: sola fide (somente pela fé), sola Scriptura (somente a Escritura), solus Christus (somente Cristo), sola gratia (somente a graça) e soli Deo Gloria (glória a Deus somente). Esses cinco pontos nucleares são as proposições teológicas que sintetizam os principais pensamentos dos reformadores, em crítica aos ensinos da Igreja Católica.

${ }^{44}$ LAUSANNE, Movimento. III Congresso Lausanne sobre Evangelização Mundial. Cidade do Cabo, 2010. Disponível in: https://www.lausanne.org/pt-br/recursos-multimidia-ptbr/compromisso-da-cidade-do-cabo-pt-br/compromisso. Acesso em 18 de maio de 2019. 45 DUPUIS, Jacques. $O$ cristianismo e as religiões: do desencontro ao encontro, p. 80-84.
} 
salvação em todos os seres humanos e em cada uma das religiões, portanto, todas as religiões são reveladas e, consequentemente, trazem consigo uma parcela da verdade 46 .

As últimas posições alinhavadas são, pois, também contrárias ao exclusivismo que é defendido pela $\mathrm{AD}$ acerca da Escritura Sagrada, em sua concepção da mesma como verdade:

[...] cremos, professamos e ensinamos que a Bíblia Sagrada é a Palavra de Deus, única revelação escrita de Deus dada pelo Espírito Santo, escrita para a humanidade e que o Senhor Jesus Cristo chamou as Escrituras Sagradas de a "Palavra de Deus"; que os livros da Bíblia foram produzidos sob inspiração divina: "Toda a Escritura é inspirada por Deus e útil" (2 Tm 3.16 - ARA[47]). Isso significa que toda a Escritura foi respirada ou soprada por Deus, o que a distingue de qualquer outra literatura, manifestando, assim, o seu caráter sui generis. As Escrituras Sagradas são de origem divina; seus autores humanos falaram e escreveram por inspiração verbal e plenária do Espírito Santo: "Porque a profecia nunca foi produzida por vontade de homem algum, mas os homens santos de Deus falaram inspirados pelo Espírito Santo" (2 Pe 1.21). Deus soprou nos escritores sagrados, os quais viveram numa região e numa época da história e cuja cultura influenciou na composição do texto. Esses homens não foram usados automaticamente; eles foram instrumentos usados por Deus, cada um com sua própria personalidade e talento. A inspiração da Bíblia é especial e única, não existindo um livro mais inspirado e outro menos inspirado, tendo todos o mesmo grau de inspiração e autoridade. A Bíblia é nossa única regra de fé e prática, a inerrante, completa e infalível Palavra de Deus: "A lei do SENHOR é perfeita" (Sl 19.7). É a Palavra de Deus, que não pode ser anulada: "e a Escritura não pode falhar" (Jo 10.35 - ARA) ${ }^{48}$.

Apesar da ênfase na verdade bíblica absoluta, pode-se dizer que o exclusivismo da $\mathrm{AD}$ é menos categórico em referência si mesma, não arrogando essa denominação cristã, para si, o título de portadora da verdade, mas autocompreendendo-se como uma daquelas instituições que, como tantas outras, professam itens doutrinais inegociáveis, tais como: Cristo como único salvador e as Escrituras como única norma de fé e prática. Além disso, a $\mathrm{AD}$ reconhece que

\footnotetext{
${ }^{46}$ QUEIRUGA, Andrés Torres. Del terror de Isaac al Abbá de Jesús. Estella (Navarra): Editorial Verbo Divino, p. 295, apud VIGIL, José Maria. Teologia do pluralismo religioso: para uma leitura pluralista do cristianismo, p. 102-103.

${ }_{47}$ A saber, versão Almeida Revista e Atualizada, da Bíblia em língua portuguesa.

${ }^{48}$ SILVA, Esequias Soares (org.). Declaração de Fé, p. 25-26. Ênfases em negrito dos autores.
} 
existem "valores positivos" em religiões diferentes do cristianismo, tais como o respeito ao próximo, o amor e a paz, que foram construídos socialmente, não tendo valor salvífico.

\subsection{O pluralismo e a posição assembleiana}

O pluralismo se constitui em um dos pontos de maior tensão para com as doutrinas assembleianas, dado que na posição pluralista existe uma presença operante, oculta, incógnita do mistério de Cristo nas mais diversas tradições religiosas, presença essa que, nas palavras de Jacques Dupuis, tem sido chamada de “cristianismo anônimo". Assim, pois, o cristão anônimo seria um tipo de cristão inconsciente de seu estado cristão, e o que distinguiria o cristão anônimo do cristão explícito seria a consciência subjetiva do último, de saber-se cristão. O cristianismo anônimo seria, pois, uma realidade fragmentada, incompleta, mas que, de certa maneira, não impediria a misteriosa ação salvífica de Cristo, sem necessariamente haver fé nem consciência da pessoa de Cristo49.

A possibilidade de um cristão anônimo ou inconsciente, contudo, é também claramente negada pela posição doutrinária assembleiana, pois, segundo a sua Declaração de Fé, um dos pontos principais consiste na afirmação da necessidade de crer-se explicitamente em Cristo.

A salvação é-nos oferecida pela graça mediante a fé no sacrifício de Jesus Cristo na cruz do Calvário. Ela é eterna, completa e eficaz. A salvação em Jesus Cristo não é um mero assentimento intelectual, e sim um renascimento espiritual que se dá na vida do pecador arrependido. No ato da aceitação, o pecador é imediata e simultaneamente salvo, justificado e adotado como filho de Deus. A partir daí, entra no processo de santificação até a sua glorificação final no dia de Cristo. Entendemos que o salvo é o pecador que Cristo resgatou das trevas e libertou do pecado e da morte espiritual e que agora está livre da condenação eterna: "Portanto, agora, nenhuma condenação há para os que estão em Cristo Jesus, que não andam segundo a carne, mas segundo o espírito. Porque a lei do Espírito de vida, em Cristo Jesus, me livrou da lei do pecado e da morte" (Rm 8.1,2). Perdão é a absolvição de uma dívida e a remissão de um castigo. Justificação é um ato da graça de Deus, o Supremo Juiz, pelo qual a justiça de Cristo é imputada a todo aquele que crê em Jesus declarando-o justo. O primeiro resultado da justificação é a paz

49 DUPUIS, Jaques. O cristianismo e as religiões: do desencontro ao encontro, p. 82-83. 
com Deus: "Sendo, pois, justificados pela fé, temos paz com Deus por nosso Senhor Jesus Cristo" (Rm 5.1). Juntamente com a salvação e a justificação, o pecador arrependido recebe a adoção de filho de Deus. A partir desse momento, terá ele um relacionamento mais íntimo com Deus, invocando-o não apenas como Criador, mas principalmente como Pai: "Porque não recebestes o espírito de escravidão, para, outra vez, estardes em temor, mas recebestes o espírito de adoção de filhos, pelo qual clamamos: Aba, Pai. O mesmo Espírito testifica com o nosso espírito que somos filhos de Deus" (Rm 8.15,16)50.

Mais uma vez, fica evidente que a posição exclusivista da $\mathrm{AD}$ é um fator preponderante para que não exista ou seja dificultado o diálogo inter-religioso. Isso se depreende não só a partir da sua Declaração de Fé, como exposto acima, mas também da vasta produção literária ligada à $\mathrm{AD}$, como livros e lições de Escola Bíblica Dominical, sob a coordenação da CPAD.

\section{Considerações finais}

Ainda que muitas religiões e instituições tenham aberto as suas portas para o diálogo inter-religioso, a $\mathrm{AD}$ adota, como regra, pressupostos doutrinais irredutíveis e impossibilitadores para tal propósito. A AD se estabeleceu tendo como mote o discurso conversionista, com forte apelo apologético e pouca abertura ao ecumenismo. A partir dessa perspectiva, é notória a dificuldade de promover o diálogo inter-religioso. Ainda que alguns membros da instituição façam tal movimento, eles não representam, nisso, a AD. Existe de maneira muito tímida a iniciativa, por parte de membros isolados, de construção de pontes dialogais, em que são buscados pontos de contato com outras religiões, visando, então, repensar a atitude exclusivista.

Mesmo que teólogos pentecostais concordem que a espiritualidade hodierna exige, como bandeira comum e de paz, a proposta do diálogo, a participação em ações afins, no contexto da $\mathrm{AD}$ em especial, ainda é muito limitada. A posição exclusivista é fortemente propagada, no tocante à defesa das Escrituras como contendo a verdade absoluta, divina e insuperável, cuja mensagem é assim resumida: todos os seres humanos são chamados à salvação em

\footnotetext{
${ }^{50}$ SILVA, Esequias Soares (org.). Declaração de Fé, p. 63-34. Ênfases em negrito dos autores.
} 
Cristo. Seja como for, a AD adota tal posição por força de convicção e percepção de autenticidade.

Não obstante isso, pertence às convicções da instituição pregar o respeito, a tolerância e o amor ao próximo em sua diferença. A Igreja Evangélica Assembleia de Deus, por óbvio, não se declara como $a$ religião ou $a$ instituição absoluta e verdadeira, mas professa, sim, que Jesus é o único Salvador e que se revelou através dos tempos, verdade essa encontrada na Escritura.

\section{Referências}

BRASIL, IBGE. Censo Demográfico 2010: características gerais da população, religião e pessoas com deficiência. Rio de Janeiro: IBGE, 2010. Disponível in: https://biblioteca.ibge.gov.br/visualizacao/periodicos/94/cd_2010_religiao_defi ciencia.pdf. Acesso em 12 de junho de 2019.

CADB (Convenção da Assembleia de Deus no Brasil). História Centenária da Assembleia de Deus no Brasil (E-book). Disponível in: <http://portalcadb.com/wp-content/uploads/2017/12/ebook-historia-daassembleia-de-deus-cadb.pdf $>$. Acesso em 18 de maio de 2019.

CARVALHO, César Moisés. A importância das Lições Bíblicas na coesão doutrinária nas Assembleias de Deus no Brasil. CPADNEWS, 2010. Disponível in: http://cpadnews.com.br/ensinador-cristao/780/a-importancia-das-licoesbiblicas.html. Acesso em 18 de maio de 2019.

DUPUIS, Jacques. O Cristianismo e as religiões - Do desencontro ao encontro. São Paulo: Loyola, 2004.

FERREIRA, Ismael de Vasconcelos. Pentecostalismo e secularização: da rigidez doutrinária ao pluralismo religioso. In: Horizonte. Ano 10, n. 28, 2012, p. 14581472 .

FRESTON, Paul. Breve história do pentecostalismo: 1. A Assembléia de Deus. In: ANTONIAZZI. Alberto et alii (orgs.). Nem anjos nem demônios: interpretações sociológicas do pentecostalismo. Petrópolis: Vozes, 1994, p. 67-99.

GILBERTO, Antônio et alii. Teologia sistemática pentecostal. Rio de Janeiro: CPAD, ${ }^{2} 2008$.

GRENZ, Stanley J.; NORDLING, Cherith Fee. Dicionário de teologia. São Paulo: Vida, 2000.

LAUSANNE, Movimento. III Congresso Lausanne sobre Evangelização Mundial. Cidade do Cabo, 2010. Disponível in: https://www.lausanne.org/pt-br/recursos- 
multimidia-pt-br/compromisso-da-cidade-do-cabo-pt-br/compromisso. Acesso em 18 de maio de 2019.

LIMA, Adriano Sousa. Assembleia de Deus no Brasil e o diálogo inter-religioso. In: Revista Caminhos de Diálogo - Pluralismo Religioso: Horizontes Abertos. Ano 2, n. 2, jan.-jul. de 2014. Disponível in: https://periodicos.pucpr.br/index.php/caminhosdedialogo/article/download/245 79/23086. Acesso em 18 de maio de 2019.

LOPES, A. N. A Bíblia e seus intérpretes - uma breve história da interpretação. São Paulo: Cultura Cristã, 32014.

MARIN, Jérri Roberto. A Assembleia de Deus e sua inserção no mercado religioso da década de 1990. In: Revista Brasileira de História das Religiões. ANPUH, n. 17, setembro de 2013 (publicada em 2014), p. 189-214.

MARIN, Jérri Roberto. A Assembleia de Deus nos anos de 1990: a "Década da Colheita”. In: Horizonte - Dossiê: Religião, Mercado e Mídia. Ano 12, n. 34, abr.jun. 2014, p. 436-464.

MENESES, Jonatas Silva. Igreja Evangélica Assembleia de Deus: movimento, continuidade e mudanças. In: Revista Lusófona de Ciência das Religiões. Ano X, nn. 18-19, 2013, p. 155-164.

MESQUITA, Antônio. Assembleia de Deus no Brasil é a maior do mundo. Site Fronteirafinal. 2010.2 Disponível in: https://fronteirafinal.wordpress.com/2011/07/02/assembleia-de-deusbrasilmaior-do-mundo. Acesso em 20 de junho de 2019.

MINA, Andréia Mendes de Souza. Pentecostalismo e alteridade: a demonização do outro no discurso da Assembléia de Deus. In: Revista Esboços. Ano 11, n. 11, 2004, p. 83-92.

MORAES, Isael de Araújo. Dicionário do Movimento Pentecostal. Rio de Janeiro: CPAD, 2007.

MORAES, Isael de Araújo. História do Movimento Pentecostal no Brasil. Rio de Janeiro: CPAD, 2016.

PAINE, Scott Randall. Exclusivismo, inclusivismo e pluralismo religioso. In: Revista Brasileira de História das Religiões - Dossiê Identidades Religiosas e História. Ano 1, n. 1, 2008. Disponível in: http://www.dhi.uem.br/gtreligiao/pdf/11\%20Scott\%20Randall\%20Paine.pdf. Acesso em 18 de junho de 2019.

PONTIFÍCIO Conselho para o Diálogo Inter-religioso. Diálogo e Anúncio. 1991. Disponível in:http://www.vatican.va/roman_curia/pontifical_councils/interelg/documents/ 
rc_pc_interelg_doc_19051991_dialogue-and-proclamatio_po.html. Acesso em 10 de maio de 2019.

SILVA, Esequias Soares (org.). Declaração de Fé. Rio de Janeiro: CPAD, 2017.

SILVA, José Barbosa da. Diálogo inter-religioso: tensões e perspectivas na interpretação da instrução diálogo e anúncio à luz da proposta teológica de Jacques Dupuis. Recife: Universidade Católica de Pernambuco (Dissertação Mestrado em Ciências da Religião), 2013, 129p. Disponível in: http://tede2.unicap.br:808o/bitstream/tede/338/1/jose_barbosa_silva.pdf. Acesso em 10 de maio de 2019.

SOUSA, Bertone de Oliveira. Religião e negação da modernidade: a leitura fundamentalista da Bíblia nas revistas de Escola Bíblica Dominical da Assembléia de Deus. In: Revista Brasileira de História das Religiões. Ano 3, v. 7, maio de 2010, p. 223-250.

TORRES QUEIRUGA, Andrés. O diálogo das religiões. São Paulo: Paulus, 1997.

WEGNER, Uwe. Exegese do Novo Testamento: manual de metodologia. São Leopoldo; São Paulo: Sinodal; Paulus, 1998.

VIGIL, José Maria. Teologia do pluralismo religioso: para uma leitura pluralista do cristianismo. São Paulo: Paulus, 2006.

Recebido em: 20/12/2019.

Aprovado em: 25/12/2019. 